NIKICA BARIĆ, viši znanstveni suradnik

Hrvatski institut za povijest

UDK 351.74(=163.41)(497.5)"1991"

Hrvatska, Zagreb, Opatička 10

$94(=163.41)(497.5)^{\prime \prime} 1991 "$

\title{
OSNUTAK I RAZVOJ SLUŽBE UNUTRAŠNJIH POSLOVA SRPSKIH AUTONOMNIH OBLASTI U HRVATSKOJ 1991.
}

\begin{abstract}
APSTRAKT: U radu su dani osnovni podaci o osnutku i razvoju službe unutrašnjih poslova srpskih autonomnih oblasti koje su u Hrvatskoj proglašene krajem 1990. i tijekom 1991. godine. Krajem 1991. te oblasti ujedinit će se u Republiku Srpsku Krajinu. U januaru 1991. u Kninu je osnovan Sekretarijat unutrašnjih poslova Srpske autonomne oblasti Krajine. U njegov sastav ušle su stanice javne sigurnosti općina na području Dalmacije, Like, Korduna i Banije koje su bile većinski naseljene srpskim stanovništvom. Te stanice izdvojile su se iz sastava hrvatskog Ministarstva unutarnjih poslova. Kasnije tijekom 1991. $i$ srpske autonomne oblasti u zapadnoj Slavoniji, odnosno istočnoj Slavoniji, Baranji i zapadnom Srijemu također su uspostavile svoja tijela unutrašnjih poslova.
\end{abstract}

Ključne riječi: Srpska autonomna oblast Krajina, Srpska autonomna oblast Zapadna Slavonija, Srpska oblast Slavonija, Baranja i zapadni Srijem, Republika Srpska Krajina, Milan Martić, Milan Babić, policija

Neposredno nakon što su 1990. u Hrvatskoj održani prvi demokratski izbori, na kojima je pobijedila Hrvatska demokratska zajednica, dolazi do nesuglasica između novih hrvatskih vlasti i Srpske demokratske stranke (SDS), koja je na spomenutim izborima došla na vlast u nekim općinama s većinskim srpskim stanovništvom, među ostalim i u Kninu. SDS, kao predvodnik srpskog pokreta u Hrvatskoj, imao je potporu vodstva Srbije na čelu sa Slobodanom Miloševićem, koje je smatralo neprihvatljivim da se, u sklopu raspleta jugoslavenske krize, Hrvatska osamostali u granicama koje je imala kao federalna jedinica u sklopu Jugoslavije, nego da u tom slučaju područja većinski ili znatnim dijelom naseljena Srbima moraju ostati u zajednica sa Srbijom. U ostvarenju ove politike vodstvo Srbije moglo je računati na potporu Jugoslavenske narodne armije (JNA).

Jedan od prvih važnijih znakova srpskog neslaganje s novim vlastima u Zagrebu bilo je otvoreno pismo koje su radnici Stanice javne sigurnosti Knin srpske nacionalnosti 3. jula 1990. uputili saveznom sekretaru za unutrašnje poslove. U njemu je navedeno da su nove hrvatske vlasti ,ekstremne“ i protusrpske, a kninski milicionari neće prihvatiti novi naziv „redarstvo“ i nove uniforme i simbole 
koji podsjećaju na one korištene od 1941. do 1945. u Nezavisnoj Državi Hrvatskoj. Knin je 5. jula posjetio hrvatski ministar unutrašnjih poslova Josip Boljkovac, kako bi razgovarao s potpisnicima otvorenog pisma. Oni su, zajedno s predstavnicima SDS-a, tražili da nitko od potpisnika ne bude suspendiran i da se u Kninu osnuje općinski sekretarijat unutrašnjih poslova (SUP), a ne kao do tada, kada je Stanica javne sigurnosti Knin bila u sastavu SUP-a Šibenik. Pred zgradom u kojoj su vođeni razgovori okupio se veliki broj građana koji su potpisnicima pisma došli dati potporu, pa je Boljkovac pristao na osnivanje SUP-a u Kninu. Sredinom augusta hrvatske vlasti odlučile su iz stanica javne sigurnosti na području sjeverne Dalmacije i Like izuzeti oružje rezervnog sastava policije, kako bi spriječile da to oružje bude iskorišteno za eventualnu pobunu srpskog stanovništva. Ta akcija samo je djelomično uspjela, a kao odgovor na nju Srbi su blokirali prometnice u sjevernoj Dalmaciji, oružje rezervnog sastava u nekim je mjestima podijeljeno srpskim civilima, a u svemu ovome sudjelovali su i neki policajci srpske nacionalnosti. JNA je spriječila intervenciju helikoptera s hrvatskim policajcima koji su letjeli prema području pobune, pod prijetnjom da će biti oboreni. Nakon nekoliko dana stanje na području sjeverne Dalmacije i Like se primirilo, ali je krajem septembra do sličnih incidenata povezanih s izuzimanjem oružja rezervnog sastava policije došlo na Baniji.

Izvršno vijeće Skupštine općine Knin je na sjednici održanoj 7. novembra 1990. prihvatilo prijedlog odluke o osnivanju općinskog SUP-a Knin, koja je upućena Skupštini općine Knin na usvajanje. ${ }^{2}$ Istoga dana Izvršno vijeće Skupštine općine Knin obratilo se i hrvatskoj Vladi, od koje je zatraženo da, u skladu s hrvatskim zakonima, da suglasnost za osnivanje općinskog SUP-a u Kninu. Navedeno je da postoji više razloga zbog kojih općinske vlasti u Kninu rade na promjenama u službi unutrašnjih poslova. Politički događaji u Hrvatskoj zahtijevaju veću „mobilnost i aktivnost“ te službe, što vrijedi i za Knin. Kada su ministar Josip Boljkovac i njegovi suradnici u julu posjetili Kninu, dali su usmena obećanja o osnutku općinskog SUP-a. Iz Knina je 30. jula nadležnim vlastima u Zagrebu upućen zahtjev za osnivanje tog tijela, ali je hrvatska Vlada to odmah odbila. Zatim je na razgovorima između predstavnika hrvatskog Sabora i Srpskog nacionalnog vijeća u Donjem Lapcu ponovno dogovoreno da hrvatska Vlada pokrene postupak za osnivanje općinskog SUP-a, ali se ništa nije promijenilo. Na temelju svega ovoga Izvršno vijeće Skupštine općine Knin ocijenilo je odnos hrvatskih vlasti prema spomenutom pitanju u „najmanju ruku neozbiljnim“, posebno ako se uzmu u obzir „ukupni politički odnosi u Republici“. Da je

${ }^{1}$ Nikica Barić, Srpska pobuna u Hrvatskoj 1990-1995, Zagreb 2005, 68-70, 77-85; Davor Marijan, „Djelovanje JNA i pobunjenih Srba u Lici 1990-1992. godine“, Senjski zbornik, svezak 33, Senj 2006, 219. Također vidjeti: Hrvatska policija u Domovinskom ratu [Zagreb 2011], $75-76$.

2 International Criminal Tribunal for the former Yugoslavia, Court Records (dalje: ICTY), Martić (IT-95-11), Exibit 00502, Republika Hrvatska, Skupština općine Knin, Izvršno vijeće, Klasa: 210-01/90-01/04, Ur. broj: 2136-02-90-2, Knin, 7. 11. 1990. 
trenutni odnos hrvatskih vlasti ,više nego neprihvatljiv“" pokazuju i događaji iz augusta 1990., kada su pripadnici Općinskog SUP-a Šibenik i Stanice javne sigurnosti Drniš namjeravali napasti „nedužni narod“ općine Knin. To nije prihvatljivo za pripadnike Stanice javne sigurnosti Knin koji su u sklopu SUP-a Šibenik, a sve spomenuto ima i negativan utjecaj na raspoloženje stanovnika općine Knin. Kada bi hrvatska Vlada prihvatila osnutak općinskog SUP-a u Kninu, bio bi to korak u vraćanju povjerenja srpskog naroda prema hrvatskim vlastima.

No, spomenuti zahtjev ubrzo će postati nevažan. U Kninu je 21. decembra 1990. proglašena Srpska autonomna oblast (SAO) Krajina koja je trebala obuhvatiti područja Dalmacije, Like, Korduna i Banije s većinskim srpskim stanovništvom. ${ }^{4}$ Izvršno vijeće SAO Krajine je na sjednici održanoj u Kninu 4. januara 1991. na prijedlog svoga predsjednika Milana Babića donijelo odluku o osnutku SUP-a SAO Krajine, kao jedinog tijela na području te autonomne oblasti koje će obavljati poslove javne sigurnosti i unutrašnje poslove. Za sekretara unutrašnjih poslova imenovan je Milan Martić, inspektor u kninskoj stanici javne sigurnosti. ${ }^{5}$

Babić je 5. januara obavijestio savezne vlasti u Beogradu, hrvatski MUP i republičke sekretarijate unutrašnjih poslova Srbije i Bosne i Hercegovine da je osnovan SUP SAO Krajine sa sjedištem u Kninu. U njegov sastav ušle su stanice javne sigurnosti Benkovac, Donji Lapac, Dvor na Uni, Glina, Gračac, Knin, Kostajnica, Obrovac, Titova Korenica i Vojnić. Također je navedeno da hrvatski MUP više nema ovlasti nad područjem SAO Krajine, iako novi SUP u Kninu, prema potrebi, može surađivati s hrvatskom policijom. ${ }^{6}$

Policijska uprava Sisak je 6. januara demantirala da su njezine policijske stanice u Dvoru na Uni, Glini i Kostajnici pristupile „nekakvom nepostojećem SUP-u Srpske krajine“, nego se one i dalje nalaze u sastavu hrvatskog Ministarstva unutarnjih poslova (MUP), a isto su hrvatskim medijima potvrdili i rukovodioci tih policijskih stanica. ${ }^{7}$ Nedugo kasnije hrvatska Vlada pozvala je predstavnike općina Benkovac, Donji Lapac, Gračac, Knin, Obrovac i Titova Korenica da dođu u Zagreb, kako bi se razgovaralo o proglašenju SAO Krajine i osnutku njezina SUP-a. No, Milan Babić to je odbio pod obrazloženjem da s hrvatskim vlastima mogu pregovarati isključivo predstavnici SAO Krajine, a ne pojedine općinske uprave koje su u sastavu te oblasti. ${ }^{8}$

${ }^{3}$ Republika Hrvatska i Domovinski rat 1990-1995, Dokumenti, Knjiga 2, Dokumenti institucija pobunjenih Srba u Republici Hrvatskoj (1990.-1991), Zagreb, Slavonski Brod 2007, dok. br. 40 .

${ }^{4}$ Opširnije o proglašenju SAO Krajine vidjeti: N. Barić, $n$. dj., 91-99.

${ }^{5}$ Isto, 105. Za osnovne biografske podatke o Milanu Martiću vidjeti: ICTY, Martić (IT95-11), „Mile Martić u hrvatskom i srpskom tisku“.

${ }^{6} \mathrm{~N}$. Barić, $n . d j ., 105$.

${ }^{7}$ A. M., ,'Nema otcjepljenja!'““, Vjesnik, Zagreb, 7. 1. 1991, 1.

${ }^{8}$ (R. I.), „Pobunjene općine pozvane na razgovor“", Vjesnik, Zagreb, 9. 1. 1991, 1. 
Hrvatski MUP je 10. januara podređenim policijskim upravama uputio dopis o izjavi koju trebaju potpisati njegovi pripadnici. Očito je bila riječ o izjavi vjernosti Hrvatskoj, a pripadnici MUP-a nisu mogli dobiti osobni dohodak dok je ne potpišu, a oni koji je odbiju potpisati trebali su biti otpušteni iz službe. Policijska uprava Šibenik dostavila je spomenuti dopis Stanici javne sigurnosti u Kninu, odnosno SUP-u SAO Krajine. Milan Martić je 16. januara na ovo odgovorio depešom koja je upućena svim stanicama javne sigurnosti koje su smatrane dijelom SUP-a SAO Krajine. Čini se da je ista depeša upućena i pojedinim stanicama javne sigurnosti u drugim dijelovima Hrvatske (Beli Manastir, Pakrac, Podravska Slatina, Vukovar). U toj je depeši Martić naveo da zahtjev hrvatskog MUP-a predstavlja još jedan „grubi nelegitimni, provocirajući čin“ nad radnicima službe unutrašnjih poslova u SAO Krajini. Njima se pokušava oduzeti „dostojanstvo“ jer su izloženi „ucjeni“ da im, ako ne izraze vjernost Hrvatskoj, neće biti isplaćen osobni dohodci, što je u suprotnosti s propisima o radnom odnosu ali prije svega predstavlja „necivilizacijski čin“. Osim toga radnici unutrašnjih poslova već su dali izjave vjernosti Jugoslaviji, koje ne namjeravaju povući. ${ }^{9}$

Nekoliko dana kasnije Martić je u Kninu izjavio novinarima da su trenutni odnosi s hrvatskom policijom napeti. Ipak je njegov SUP spreman na suradnju s hrvatskom policijom, ali bez ,ikakvih ucjena“. Martić je ipak istaknuo da, dok je on živ, u Knin neće ući „redarstvenici, ni šahovnica“. Na pitanje novinara kako će se financirati novi SUP, Martić je odgovorio da će to riješiti „onaj tko ga je osnovao". ${ }^{10}$

Martić je 14. januara uputio depešu stanicama javne sigurnosti Benkovac, Donji Lapac, Gračac, Obrovac i Titova Korenica. Od njih je zatražio podatke o broju zaposlenih i sistematizaciji radnih mjesta, kako bi se mogao izraditi pravilnik o osobnim dohodcima i novoj sistematizaciji radnih mjesta SUP-a SAO Krajine. ${ }^{11}$ Izvršno vijeće SAO Krajine je 19. januara donijelo odredbu o unutrašnjoj organizaciji i radu SUP-a SAO Krajine. U skladu s njom određeno je da taj sekretarijat obavlja poslove javne i državne sigurnosti, kao i druge unutrašnje poslove. U svakoj općini SAO Krajine trebala je djelovati stanica javne bezbjednosti, dok je poslove takve stanice u Kninu trebao obavljati neposredno SUP SAO Krajine. ${ }^{12}$

${ }^{9}$ ICTY, Martić (IT-95-11), Exibit 00514, SAO Krajina, SUP-a Knin, Depeša br. 511-9321-47/91/1-1., Knin, 16. 1. 1991; Mirko Ćuruvija, „Kninjani vraćaju oružje/Tko plaća novi SUP?“, Vjesnik, Zagreb, 17. 1. 1991., 1., 14.

${ }^{10}$ Mirko Ćuruvija, „Kninjani vraćaju oružje/Tko plaća novi SUP?“, Vjesnik, Zagreb, 17. 1. 1991., 1., 14.

${ }^{11}$ ICTY, Martić (IT-95-11), Exibit 00513, SAO Krajina, SUP-a Knin, Depeša broj: 123/91., Knin, 14. 1. 1991.

${ }^{12}$ Državni arhiv Sisak, Sabirni arhivski centar Petrinja, Nesređena građa Skupštine općine Petrinja, Izvršno vijeće Srpske autonomne oblasti Krajina, Broj: 09/19-1, Knin, 19. 1. 1991, Uredba o unutrašnjoj organizaciji i radu Sekretarijata za unutrašnje poslove. 
Kao što je prethodno navedeno, kada je proglašeno osnivanje SUP-a SAO Krajine navedeno je da će u njegovom sastavu biti i stanice javne sigurnosti općina Banije i Korduna. No, također je vidljivo da je Martić podatke o broju zaposlenih i sistematizaciji radnih mjesta zatražio samo od stanica Benkovac i Obrovac u Dalmaciji i stanica Donji Lapac, Gračac i Titova Korenica u Lici. Na temelju ovoga može se pretpostaviti da je SUP SAO Krajine neposredno nakon svog osnutka imao stvarnu kontrolu i mogao se osloniti samo na spomenute stanice. Ovo potvrđuje i podatak iz februara 1991., kada se razmatralo osnivanje Savjeta SUP-a SAO Krajine. I tada je zaključeno da kandidate za to tijelo treba predložiti SUP u Kninu, kao i stanice javne bezbjednosti Benkovac, Donji Lapac, Gračac, Obrovac i Titova Korenica. ${ }^{13}$

Tek kasnije, odnosno od sredine 1991., paralelno sa širenjem ratnih sukoba u Hrvatskoj, krajinski Srbi poduzeli su stvarne korake za uspostavu službe unutrašnjih poslova na Baniji i Kordunu. Tako je primjerice u januaru 1991. najveći dio radnika Policijske stanice u Dvoru na Uni odbio potpisati izjavu vjernosti Republici Hrvatskoj, koju je hrvatski MUP uputio svojim pripadnicima nakon osnutka SUP-a SAO Krajine, nakon čega se postavilo pitanje kako će policajci iz Dvora dobiti osobne dohotke, odnosno hoće li biti otpušteni iz službe. ${ }^{14}$ No, čini se da se stanje tijekom idućih mjeseci zapravo nije promijenilo. Tek 13. juna 1991. Skupština općine Dvor na Uni donijela je odluku da se Policijska stanica Dvor na Uni izdvaja iz sastava Policijske uprave Sisak. Umjesto toga osniva se SUP Dvor na Uni koji ulazi u sastav krajinske službe unutrašnjih poslova. U skladu s ovim Izvršno vijeće Skupštine općine Dvor na Uni ovlašteno je da, zavisno od političke i sigurnosne situacije, odredi kada će biti preuzeta Policijska stanica, odnosno osnovan SUP u Dvoru na Uni, a radnici u policijskoj stanici tada su trebali biti preuzeti i raspoređeni na posao u novom SUP-u. ${ }^{15}$ Predsjedništvo Skupštine općine Vojnić je 30. jula donijelo odluku da se Policijska stanica Vojnić, do tada u sastavu Policijske uprave Karlovac, preimenuje u Stanicu javne bezbjednosti Vojnić i da ulazi u sastav MUP-a SAO Krajine. ${ }^{16}$ Izvršni savjet Skupštine općine mjesnih zajednica Petrinja s većinskim srpskim stanovništvom je krajem augusta 1991. odlučio osnovati stanicu milicije, koja je započela djelovati početkom septembra. Nakon što su krajinski Srbi i JNA sredinom istog mjeseca zauzeli grad Petrinju u njemu je uspostavljena Stanica javne bezbjednosti. ${ }^{17}$

${ }^{13}$ ICTY Martić (IT-95-11), Srpska autonomna oblast Krajina, Sekretarijat za unutrašnje poslove Knin, Knin, dana 19. 2. 1991, Sistematizacija novih radnih mjesta u Odjelu za operativne poslove.

${ }^{14}$ N. Barić, $n . d j ., 106$.

${ }^{15}$ ICTY, Martić (IT-95-11), Exibit 00470, Opštinska skupština Dvor, Klasa: 021-05/9101/81, Urbroj: 2120-01-2-91-1, Dvor, 13. 6. 1991., Odluka o izdvajanju Policijske stanice Dvor na Uni iz MUP-a Republike Hrvatske - Policijska uprava Sisak i osnivanje SUP-a Dvor na Uni i njegovom pripajanju MUP-u SAO Krajina.

${ }_{16}$ Republika Hrvatska i Domovinski rat 1990.-1995., Dokumenti, Knjiga 2., dok. br. 93.

${ }^{17}$ N. Barić, $n$. dj., 346. 
U međuvremenu su zaoštreni odnosi između krajinskih Srba i hrvatskih vlasti tijekom prve polovice 1991. doveli do ozbiljnijih oružanih sukoba. Srpski zastupnici u Skupštini općine Pakrac su krajem februara te godine donijeli odluku o pristupanju SAO Krajini, dok je policijska stanica u tom mjestu preimenovana u Općinski SUP i podređena SUP-u SAO Krajine u Kninu. Policajci srpske nacionalnosti ubrzo su preuzeli stanicu u Pakracu, nakon čega je 2. marta došlo do intervencije hrvatske policije, koja je ponovno uspostavila nadzor nad policijskom stanicom. Krajem marta općinske vlasti u Titovoj Korenici odlučile su preuzeti upravu nad Nacionalnim parkom Plitvička jezera, a tu odluku provela je krajinska milicija. Na ovo je intervenirala hrvatska policija, koja je 31. marta potisnula krajinske Srbe iz nacionalnog parka. ${ }^{18}$

Nakon što je 12. maja 1991. u SAO Krajini proveden referendum za njezino prisajedinjenje Srbiji, odnosno ostanak u Jugoslaviji, 29. maja dotadašnji Statut SAO Krajine je, uz potrebne izmjene, proglašen njezinim Ustavnim zakonom. Odmah zatim, 31. maja, proglašeni su i zakoni o Vladi SAO Krajine i njezinim ministarstvima. Tako je dotadašnje Izvršno vijeće SAO Krajine na čelu s Milanom Babićem reorganizirano u Vladu. ${ }^{19}$ Član 7. Zakona o ministarstvima SAO Krajine definirao je poslove MUP-a SAO Krajine. ${ }^{20}$ Na početku je za ministra unutrašnjih poslova određen Dušan Vještica, blizak suradnik Milana Babića. Vještica je 7. juna kao ministar unutrašnjih poslova donio nekoliko rješenja o postavljanju i smjeni osoba na rukovodećim mjestima u Stanici javne bezbjednosti Knin. ${ }^{21}$

No, imenovanje Vještice za ministra unutrašnjih poslova, što je očito bio Babićev izbor, odmah je dovelo do sukoba između Martića i Babića. Milicionari vjerni Martiću, dotadašnjem sekretaru SUP-a SAO Krajine, odbili su kadrovska rješenja koja je odredio Vještica, a također su se povukli s poslova osiguranja Babića. ${ }^{22}$ Ovaj sukob razriješen je kada je krajem juna 1991. Martić izabran za ministra unutrašnjih poslova, dok je Vještica postao ministar za urbanizam, stambeno-komunalne djelatnosti i građevinarstvo. ${ }^{23}$

${ }^{18}$ Opširnije o tome vidjeti: N. Barić, n. dj., 114.-117.; Davor Marijan, Slom Titove armije, Jugoslavenska narodna armija i raspad Jugoslavije 1987.-1992., Zagreb 2008., 241.-249.

${ }^{19}$ Opširnije o djelovanju Vlade SAO Krajine vidjeti: Nikica Barić, „Djelovanje Vlade Srpske autonomne oblasti Krajine tijekom 1991.“, Časopis za suvremenu povijest, br. 1, Zagreb 2008., 65-84.

${ }^{20}$ Zakon o ministarstvima Srpske autonomne oblasti Krajina, Glasnik Krajine, Službeni list Srpske autonomne oblasti Krajina i opština: Benkovac, Donji Lapac, Gračac, Knin, Korenica i Obrovac, Knin, br. 4, 5. 6. 1991., 179.-181.

${ }^{21} \mathrm{Za}$ spomenuta rješenja vidjeti: ICTY, Martić (IT-95-11), Exibits 00545, 00546, 00547, 00548, 00549, 00550. informacija.

${ }^{22}$ ICTY, Martić (IT-95-11), Exibit 00544, SDB SAOK, 11. 06. 1991., Presek aktuelnih

${ }^{23}$ Rješenje o izboru ministra unutrašnjih poslova Srpske Autonomne Oblasti Krajine, Rješenje o izboru ministra za urbanizam, stambeno-komunalne djelatnosti i građevinarstvo Srpske Autonomne Oblasti Krajine, Glasnik Krajine, Knin, br. 6, 2. 7. 1991., 205. 


\section{MUP SAO Krajine u ratnim djelovanjima tijekom druge polovice 1991. godine}

Izvršno vijeće SAO Krajine je 1. aprila 1991, odmah nakon sukoba s hrvatskom policijom na Plitvičkim jezerima, usvojilo zaključak da se od Vlade Republike Srbije zahtjeva da snage MUP-a Srbije pruže tehničku i kadrovsku pomoć SUP-u SAO Krajine. ${ }^{24}$

Nedugo kasnije u Knin je stigao Dragan Vasiljković, „Kapetan Dragan“, koji je u obližnjem Golubiću počeo provoditi obuku za specijalne jedinice MUPa SAO Krajine. Zajedno s Vasiljkovićem u Knin su po istom zadatku stigli radnici MUP-a Srbije, Franko Simatović „Frenki“ i Dragoljub Filipović „Fićo“. ${ }^{25}$ Tako je u Golubiću počela obuka za ljudstvo koje je stizalo iz svih dijelova SAO Krajine. ${ }^{26}$ Te jedinice, kao i Kapetan Dragan osobno, sudjelovale su u borbama protiv hrvatskih snaga, primjerice krajem jula 1991. na Baniji. ${ }^{27}$

Kako su se od sredine 1991., nakon osamostaljenja Hrvatske, ratni sukobi intenzivirali, SAO Krajina aktivirala je i svoje jedinice Teritorijalne obrane (TO). Prema nekim podacima s početka septembra te godine, TO u SAO Krajini bila je „masovnija organizacija“, sa sistemom općinskih i regionalnih štabova. Istovremeno je krajinska milicija imala 1200 aktivnih i 1200 rezervnih milicionara, kao i 500 pripadnika milicijskih jedinica posebne namjene, od čega je 100 bilo „elitno obučeno“, što se, očito, odnosilo na ljudstvo koje je prošlo obuku Kapetana Dragana u Golubiću. Prema istim podacima milicija je bila dobro naoružana, ali su joj nedostajale uniforme, sredstava veze i motorna vozila. Isto tako ni u tom razdoblju nije bilo riješeno pitanje osobnih dohodaka za pripadnike milicije. $^{28}$

U okolnostima koje su vladale tijekom druge polovice 1991. MUP SAO Krajine bio je u cjelini znatno angažiran u ratnim djelovanjima. Vlada SAO Krajine je 9. oktobra odredila da sve jedinice milicije u planiranju i izvođenju borbenih zadataka budu podređene nadležnim štabovima krajinske TO. ${ }^{29}$ Tako je primjerice Odjeljenje milicije Plaški iz sastava Stanice javne bezbjednosti Ko-

${ }^{24}$ Republika Hrvatska i Domovinski rat 1990.-1995., Dokumenti, Knjiga 2., dok. br. 73.

${ }^{25}$ ICTY, Martić (IT-95-11), Exibit 00619, Informacija str. pov. br. 437, 28. 8. 1991., Vojna tajna, Strogo poverljivo, Br. evidencije 119, Neka saznanja o Danielu Sneddenu, državljaninu Australije, alias „Kapetan Dragan“, Načelnik III odelenja UB SSNO, pukovnik Milorad Bošković. Također vidjeti: Nedeljnik „Vreme“ i filmska produkcija „Vreme film“, Dokumentarni serijal „Jedinica“, Beograd 2006.

${ }^{26}$ Republika Hrvatska i Domovinski rat 1990.-1995., Dokumenti, Knjiga 1., Oružana pobuna Srba u Hrvatskoj i agresija Oružanih snaga SFRJ i srpskih paravojnih postrojbi na Republiku Hrvatsku (1990.-1991.), Zagreb 2007., dok. br. 61. 50.-57.

${ }^{27}$ Jakša Raguž, „Boj za Strugu“, VP - Magazin za vojnu povijest, br. 4, Zagreb, jul 2011.,

${ }^{28}$ Milisav Sekulić, Knin je pao u Beogradu, Bad Vilbel 2001., 31.

${ }^{29}$ N. Barić, Srpska pobuna u Hrvatskoj, 344. 
renica po naredbama Štaba TO Plaški tijekom novembra 1991. sudjelovalo u zauzimanju Saborskog i Slunja. ${ }^{30}$

Prema kraju 1991. MUP SAO Krajine poduzimao je daljnje mjere na svojoj organizaciji i rješavanju problema proisteklih iz postojećih ratnih uvjeta. Predstavnici iz Dubice (općina Kostajnica) su krajem novembra posjetili Knin, kako bi se ministru Martiću požalili na „šarene“, odnosno pripadnike srpskih jedinica koji su nosili kamuflažne uniforme. Oni su se predstavljali kao pripadnici MUP-a SAO Krajine, a isticali su se samovoljnim postupcima i nasiljem nad hrvatskim stanovništvom. Martić je posjetio područje Kostajnice, kako bi ispitao stanje na tom području. ${ }^{31}$ Zatim je 26. novembra naredio da Stanica javne bezbjednosti Kostajnica, zajedno s Vojnom policijom Banjalučkog korpusa JNA i nadležnim odredom krajinske TO, preuzme poslove održavanja javne sigurnosti na području Dubice. Također je što hitnije trebalo stvoriti uvjete za uspostavu redovne mirnodopske milicije u Dubici. Osobe koje nose „šarene uniforme“ a nisu pripadnici MUP-a SAO Krajine trebali su vratiti oznake milicije, te su trebali biti mobilizirani $u$ ratne formacije JNA. ${ }^{32}$

U MUP-u SAO Krajine u Kninu je 11. decembra održan sastanak, nakon kojeg je objavljeno saopćenje. U njemu je navedeno da su na sastanku imenovani načelnici stanica javne bezbjednosti u Slunju i za područje Karlovca, sa sjedištem u Tušiloviću. Objavljeni su i podaci o podnesenim krivičnim prijavama i zahtjevima za pokretanje prekršajnog postupka, kao i o drugim mjerama koje je poduzeo krajinski MUP. Također je navedeno da se u zatvorima u Glini, Kninu, Korenici, Slunju i Vrginmostu nalazi 128 osoba, najvećim dijelom pripadnika hrvatskih vojnih i policijskih snaga, a od „paravojnih formacija Hrvatske“ zaplijenjene su i veće količine oružja i municije. U saopćenju su građani koji pripadaju „hrvatskim paravojnim formacijama“ pozvani da vrate naoružanje i vojnu opremu u stanice javne sigurnosti na području svoje općine, a krajinski MUP im garantira zaštitu. ${ }^{33}$

Konačno je 19. decembra 1991. u Kninu proglašena Republika Srpska Krajina (RSK). Na samom kraju iste godine, 30. decembra, u Kninu je u MUP-u novoproglašene republike održan novi radni sastanak kojem su prisustvovali ministar Martić, njegovi pomoćnici, načelnik SUP-a Knin i načelnici stanica javne bezbjednosti „svih petnaest krajiških opština“. Kako je objavljeno u kasnijem saopćenju na sastanku je zaključeno da je stanje u RSK ,sigurno i bez-

${ }^{30}$ ICTY, Martić (IT-95-11), Exibit 00605, Stanica javne bezbjednosti Korenica, Odjeljenje milicije Plaški, Plaški, 23. 11. 1991. godine, Izvještaj o učestvovanju odjeljenja milicije Plaški u borbenim dejstvima za protekli period.

31 Dušan Glavaš, Naša Krajina, Ratni dnevnik 1990-1995. godine, Beograd 2005., $74-78$.

${ }^{32}$ ICTY, Martić, (IT-95-11), Exibit 00602, Srpska autonomna oblast Krajina. Ministarstvo unutrašnjih poslova, Broj: 4263/1-91, Knin, 26. 11. 1991, Naredba.

33 Republika Hrvatska i Domovinski rat 1990.-1995, Dokumenti, Knjiga 1., dok. br. 286 . 
bedno“, unatoč hrvatskog pokušaja bombardiranja Knina ${ }^{34}$ i planova „ustaške vrhuške“ o ubacivanju „diverzantsko terorističkih grupa“. MUP RSK ,garantira svim narodima bezbjednost na ovim prostorima“, te apelira na građane da zaštite one „drugih nacionalnosti“ jer, unatoč svih događaja, u RSK postoje uvjeti za „suživot". 35 Ovo posljednje ukazivalo je na nepovoljan položaj hrvatskog stanovništva na područjima pod kontrolom krajinskih Srba.

\section{Služba državne bezbjednosti MUP-a SAO Krajine}

Podaci o djelovanju Službe državne bezbjednosti (SDB-a) MUP-a SAO Krajine su vrlo fragmentarni. Štoviše, nije mi poznato ni tko je bio načelnik te službe. ${ }^{36}$

Zanimljiv je dokument SDB-a MUP-a SAO Krajine „Presek aktuelnih informacija“ od 11. juna 1991. godine. U njemu je navedeno da je za ministra unutrašnjih poslova izabran Dušan Vještica, Babićev pristaša. SDB je radio na tome da o Vještici prikupi kompromitirajuće materijale, kako bi pokazala da se on prethodno bavio „privrednim kriminalom“. Iz ovoga je očito da je SDB davala potporu Milanu Martiću da on, kao dotadašnji krajinski sekretar SUP-a, postane i novi ministar unutrašnjih poslova SAO Krajine. No, u istom je dokumentu također navedeno da neki Martićevi potezi predstavljaju „preuranjenu improvizaciju“. ${ }^{37}$ Iz takvog sadržaja spomenutog dokumenta može se pretpostaviti da ni Babić niti Martić nisu imali kontrolu nad SDB-om SAO Krajine. To otvara pitanje kome je načelnik SDB-a SAO Krajine bio odgovoran, odnosno kome je bio upućen spomenuti pregled aktualnih informacija. Moguće je da su te informacije bile upućene SDB-u MUP-a Republike Srbije.

Babić je očito shvaćao da ne može računati na SDB, pa je kao krajinski premijer početkom augusta 1991. donio odluku o ukidanju te službe. Umjesto nje trebala je biti osnovana nova „Vladina agencija za nacionalnu bezbednost“. No, ta agencija do kraja 1991., a niti kasnije, nije započela djelovati. ${ }^{38}$ Osim pokušaja da osnuje službu državne bezbjednosti na koju će se moći osloniti Babić je također bio nezadovoljan djelovanjem Kapetana Dragana, a težio je imati i punu ko-

${ }^{34}$ Hrvatska vojska po prvi put je bombardirala Knin 25. decembra 1991. Vidjeti: Republika Hrvatska i Domovinski rat 1990.-1995., Dokumenti, Knjiga 5., Dokumenti vojne provenijencije „Republike Srpske Krajine“ (srpnja - prosinac 1992.), Zagreb 2009., dok. br. 280.

${ }^{35}$ ICTY, Martić (IT-95-11), Exibit 00966, Republika Srpska Krajina, Ministarstvo unutrašnjih poslova, Knin, 31. 12. 1991.

${ }^{36}$ Primjerice na jednom dokumentu na kojem bi trebao stajati potpis načelnika SDB-a MUP-a SAO Krajine, toga potpisa nema. Vidjeti: ICTY, Martić (IT-95-11), Srpska autonomna oblast Krajina, Ministarstvo unutrašnjih poslova, Služba državne bezbednosti, Knin, 11. 11. 1991, Predmet: Informacija o nekim problemima u radu SDB.

${ }^{37}$ ICTY, Martić (IT-95-11), Exibit 00544, SDB SAOK, 11. 6. 1991., Presek aktuelnih informacija.

\footnotetext{
${ }^{38}$ N. Barić, Srpska pobuna u Hrvatskoj, 220.
} 
mandu nad krajinskom TO. ${ }^{39}$ Težnja Babića da ima glavnu riječ u svim pitanjima važnim za Krajinu kulminirat će početkom 1992. u njegovom sukobu sa Slobodanom Miloševićem po pitanju prihvaćanja Vanceova mirovnog plana, nakon čega će Babić biti smijenjen s vodećih dužnosti u RSK.

\section{Osnutak službe unutrašnjih poslova SAO Zapadne Slavonije i Srpske oblasti Slavonija, Baranja i zapadni Srijem}

SAO Zapadna Slavonija proglašena je 12. augusta 1991. u okolici Pakraca, a odmah zatim na tom području izbili su intenzivniji sukobi između hrvatskih snaga i krajinskih Srba, pri čemu je srpska strana imala potporu JNA. ${ }^{40}$

$\mathrm{Na}$ temelju dostupnih podataka može se zaključiti da su u zapadnoj Slavoniji organizaciju službe unutrašnjih poslova, odnosno milicije potaknule strukture TO, a ne civilne vlasti SAO Zapadne Slavonije. Tako je Štab TO SAO Zapadne Slavonije 2. septembra 1991. naredio formiranje specijalne jedinice milicije. Za komandira je određen Krsta Žarković. Općinski štabovi TO Zapadne Slavonije trebali su u tu jedinicu uputiti dio svojih ljudi, kojih je ukupno trebalo biti 60 , a to su trebali biti ,prvenstveno milicionari koji su završili obuku i bili pripadnici specijalnih jedinica, pripadnici TO dobrovoljci psihofizičkih sposobnosti do 30 godina starosti, po mogućnosti vojni policajci i sportisti““. ${ }^{41}$ Krsta Žarković bio je bivši pripadnik jedinice za posebne namjene Republičkog SUP-a Socijalističke Republike Hrvatske, a do 1. jula 1991. radio je u hrvatskoj policiji u Daruvaru. $^{42}$

Početkom oktobra 1991. Štab TO SAO Zapadne Slavonije izdao je novu naredbu o formiranju jedinice milicije za posebne namjene pri SUP-u Pakrac, koja je trebala imati 100 do 120 pripadnika. ${ }^{43}$

Osim spomenute specijalne jedinice milicije, koja je očito trebala biti korištena za vojne zadatke, organizirane su i milicijske stanice za održavanje javnog reda. Tako je primjerice Općinski štab TO Grubišno Polje sredinom septembra 1991. odredio pravila službe stanice milicije za tu općinu. Ona je definirana kao „,izvršni organ legalne vlasti“ sa zadatkom brige o redu, miru i sigurnosti građana. Milicija je trebala izvršavati redovne naredbe svoga starješine ili Općinskog štaba TO, dok je o svom radu trebala izvještavati komandanta istog štaba. ${ }^{44}$

${ }^{39}$ N. Barić, „Djelovanje Vlade Srpske autonomne oblasti Krajine tijekom 1991.“, 73-74; D. Marijan, Slom Titove armije, 288.

${ }^{40}$ Davor Marijan, Novska u Domovinskom ratu, Novska 2009., 169.-174.

${ }^{41}$ Republika Hrvatska i Domovinski rat 1990.-1995., Dokumenti, Knjiga 1., dok. br. 145.

${ }^{42}$ ICTY, Martić (IT-95-11), Exibit 00539, Žarković Krsta, Stara Gradiška (814-788), Partizansko naselje bb, Biografija.

${ }^{43}$ Republika Hrvatska i Domovinski rat 1990.-1995., Dokumenti, Knjiga 1., dok. br. 197.

${ }^{44}$ Isto, dok. br. 160. 
Redovnom organiziranju službe unutarnjih poslova u zapadnoj Slavoniji moglo se pristupiti tek nakon Sarajevskog primirja početkom 1992. godine. Tako je 24. januara 1992. Milan Martić donio odluku o formiranju regionalnog SUP-a Pakrac s privremenim sjedištem u Okučanima, koji je trebao organizirati službu unutrašnjih poslova na području zapadne Slavonije. ${ }^{45}$

Velika narodna skupština Srpske oblasti Slavonije, Baranje i Zapadnog Srijema je 25. septembra 1991. donijela Zakon o ministarstvima. Član 7. zakona definirao je poslove MUP-a te srpske oblasti. ${ }^{46} \mathrm{Za}$ ministra unutrašnjih poslova izabran je Borislav Bogunović. ${ }^{47}$ Prema nekim podacima Bogunović i njegovo ministarstvo su se u nepovoljnim ratnim okolnostima koje su vladale u jesen 1991. slabo snalazili u obavljanju poslova za koje su bili zaduženi. U decembru iste godine Bogunović je smijenjen s te dužnosti. ${ }^{48}$

Još i prije osnivanja oblasnog MUP-a, na području Baranje je, nakon što su iz nje potisnute hrvatske snage, djelovao Općinski SUP Beli Manastir. ${ }^{49}$ SUP Vukovar osnovan je 18. oktobra 1991. godine. Prije toga na vukovarskom području pojedini štabovi TO i organi civilnih vlasti osnivali su manje stanice milicije koje nisu bile međusobno povezane, niti popunjene dovoljnim brojem ljudi. Štab TO Slavonije, Baranje i zapadnog Srijema osnovao je i stanice milicije u Iloku, Tovarniku, Oroliku i Mirkovcima, koje su uglavnom popunjene radnicima MUP-a Republike Srbije. SUP Vukovar je nakon osnutka i do početka 1992. uspostavio organizaciju službe unutrašnjih poslova na svom području djelovanja. ${ }^{50}$

Sarajevsko primirje početkom januara 1992. i početak provedbe UNovog mirovnog plana u Hrvatskoj (,Vanceov plan“) omogućit će da MUP RSK u nešto povoljnijim uvjetima do kraja razvije svoju strukturu. No, krajinska službe unutrašnjih poslova i dalje će, sve do sloma RSK, biti opterećena djelovanjem u ratnom okruženju, odnosno uvjetima, kao i svim s tim povezanim društvenim i ekonomskim problemima.

${ }^{45}$ ICTY, Martić (IT-95-11), Republika Srpska Krajina, Ministarstvo unutrašnjih poslova, Broj: 01-197/1-92., Knin, 24. 1. 1992.

${ }^{46}$ Zakon o ministarstvima, Službeni glasnik Srpske oblasti Slavonija, Baranja i zapadni Srem, br. 1, 19. 12. 1991., 6.-8.

${ }^{47}$ Odluka o izboru predsednika i potpredsednika Vlade Srpske Oblasti Slavonija, Baranja i Zapadni Srem i ministara u Vladi Srpske Oblasti Slavonija, Baranja i Zapadni Srem, Službeni glasnik Srpske oblasti Slavonija, Baranja i zapadni Srem, br. 1, 19. 12. 1991., 9.

${ }^{48}$ Ilija Petrović, Slavonija, Baranja i zapadni Srem, Od Vijeća do Republike, Novi Sad 1996., 103.-104.

${ }^{49}$ Republika Hrvatska i Domovinski rat 1990.-1995., Dokumenti, Knjiga 1., dok. br. 152.

${ }^{50}$ Republika Hrvatska i Domovinski rat 1990.-1995., Dokumenti, Knjiga 6., Dokumenti institucija pobunjenih Srba u Hrvatskoj (srpanj - prosinac 1992.), Zagreb, Slavonski Brod, 2009., dok. br. 4. 


\title{
Nikica Barić
}

\section{ORGANIZATION AND DEVELOPMENT OF THE INTERNAL AFFAIRS SERVICES OF THE SERB AUTONOMOUS REGIONS IN CROATIA DURING 1991}

\begin{abstract}
Summary
The article presents the foundation and development of the internal affairs services of the Serb autonomous regions that were established in Croatia in late 1990 and during 1991. In late 1991 these regions united into new Republic of Serb Krajina. The Secretary of Internal Affairs of Serb Autonomous Region Krajina was established in Knin in January 1991 and it included police stations in municipalities mostly inhabited by ethnic Serbs in central regions of Croatia (northern Dalmatia, Lika, Kordun and Banija regions). After creating their own police organization Serb leadership in Knin declared that orders by Croatian Ministry of Internal Affairs are null and void on the territory of their autonomous region. During summer and autumn of 1991 Serb autonomous regions in western and eastern Slavonia also created their own police structures. First armed clashed between Croatian police and Krajina Serbs occurred during first half of 1991. After Croatian declaration of independence in late June 1991 armed conflicts intensified as Krajina forces and Yugoslav People's Army took control over areas that were to stay under Serb control and within the rump Yugoslav state. For these reasons during second half of 1991 Krajina Serbs' police forces, special units as well as regular policemen, were often used as military forces, although Krajina Serbs also had its territorial defense units.
\end{abstract}

